\title{
Use of $\delta^{18} \mathrm{O}$ in the interpretation of hydrological dynamics in lakes
}

\author{
Matteo PERINI, Federica CAMIN, Flavio CORRADINI ${ }^{1)}$, Ulrike OBERTEGGER ${ }^{1)}$ and Giovanna FLAIM ${ }^{1) *}$ \\ FEM-IASMA Research Center - Agrifood Quality Department, Via E. Mach, 1 - 38010 San Michele all'Adige (TN), Italy \\ ${ }^{1)}$ FEM-IASMA Research Center - Natural Resources Department, Via E. Mach, 1 - 38010 San Michele all'Adige (TN), Italy \\ *e-mail corresponding author: giovanna.flaim@iasma.it
}

\begin{abstract}
Stable isotopes offer an opportunity to investigate lake dynamics in the absence of whole catchment studies. This study considered multi-year $\delta^{18} O$ values for six different lakes located in the Italian Alps. We studied $\delta^{18} O$ values of two large (L. Caldonazzo and L. Levico) and four small lakes (L. Lavarone, L. Santo di Cembra, L. Serraia, and L. Tovel) characterised by different hydrological regimes $(>$ or $<1$ year renewal time) and size $(>$ or $<50$ ha). Differences in isotope composition along the water column, between years and layers were used to investigate the extend of lake water renewal, mixis, stratification, and groundwater infiltration. Lakes with short renewal time had significantly different spring overturn values, while lakes with longer renewal time had substantially constant values. The isotope content of the water column also clarified the extent of mixis for some lakes: Lavarone underwent complete mixing only in some years, while Tovel, previously considered meromictic, could no longer be considered as such. With the exception of L. Tovel, characterised by a peculiar hydrology, thermal stratification was reflected in yearly isotope patterns. Analysis of hypolimnetic isotope values indicated that in L. Lavarone and L. Serraia strong storm events altered summer hypolimnetic $\delta^{18} O$ values suggesting groundwater infiltration. Furthermore, epilimnetic isotope enrichment was related to lake elevation by a linear relationship. The extraordinarily hot 2003 summer led to a higher evaporation with respect to other years considered. Multi-annual data on the isotopic values of rainfall for L. Tovel (1178 $\mathrm{m}$ a.s.l.) provided the necessary background for data interpretation since precipitation governs isotope inputs. Based on our data, we proposed a general scheme of the seasonal $\delta^{18} O$ pattern in temperate lakes distinguishing between small and large lakes.
\end{abstract}

Key words: stable oxygen isotopes; hydrology; stratification; mixis; lake renewal; small lakes

\section{INTRODUCTION}

Stable isotopes are an innovative tool to investigate biological (Grey et al. 2004) and physical (Gibson et al. 2002) aspects of lakes. Lakes are an important part of the landscape with over $90 \%$ of the world's water bodies smaller than 50 ha and accounting for over $37 \%$ of the total lake surface area (Lehner \& Döll 2004). Locally, lakes are essential sources of drinking water, irrigation, recreation, and electrical power production, and their conservation and management is important for end users. Despite their numerical prevalence and rich biological diversity (Williams et al. 2003), small water bodies have received limited attention, with limnological research traditionally focusing on larger lakes (Wetzel 2001).

Because of their reduced size $(<50 \mathrm{ha})$, small lakes are particularly vulnerable to ecological changes caused both by global change and by local land-use. While global change is outside the scope of direct management strategies, the relation of groundwater to surface waters and ultimately land-use has been of growing interest to water management agencies and stakeholders because of concerns related to eutrophication (Winter 1995). Furthermore, small lakes will tend to be more affected by short-term perturbations related to extraordinary hydrological events such as floods or droughts that may be buffered in larger lakes (Gibson et al. 2002). Hydrology, intended in the broad sense of residence time, water levels, inflow/outflow, etc., is probably the most overlooked factor in limnological studies, but de facto determines stratification, water temperature, nutrient distribution, and to a great extent community structure (Ambrosetti et al. 2002; Corradini et al. 2004; Obertegger et al. 2007). Often though, economic, technical, and logistic constraints impede a complete hydrological evaluation of water sources to the lake (Winter 1995; Gibson 2001), but an understanding of source and timing of inflow from the lakes' catchment is essential to model and manage aquatic ecosystems (McEacherm et al. 2006). For this reason, along with the more traditional methods of hydrodynamic studies in lakes and rivers, analysis of the isotopic ratio ${ }^{18} \mathrm{O} /{ }^{16} \mathrm{O}$ of water has become increasingly used, providing a new tool to improve our understanding of the hydrological processes that govern small lakes (Rozanski et al. 2000; Gibson et al. 2002).

In temperate lakes, the isotope composition is generally homogeneous during spring and autumn mixing, while as stratification progresses, the epilimnion tends to become enriched in heavy isotopes (Gat 1995). The hypolimnion, on the other hand, is theoretically isolated and usually shows no significant changes in its isotope ratio with respect to values at the beginning of stratifi- 


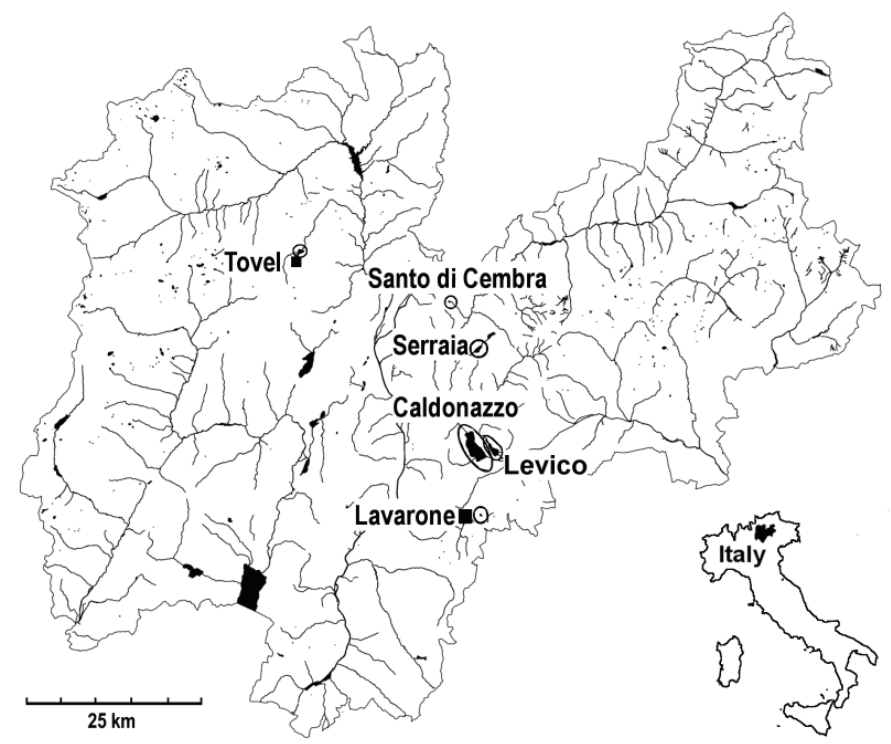

Fig. 1. Location of lakes in Trentino, Italy.

Tab. 1. Geographical, physical, and limnological characteristics of the lakes studied (data from IASMA 1996-2000). * data from Alpine Lake Network (www.alplakes.org); **n.a. not available; catchment area and consequent renewal time not available because lake is located under a ridge/divide with direction of underground water flow unknown.

\begin{tabular}{|c|c|c|c|c|c|c|}
\hline Parameters & L. Caldonazzo & L. Lavarone & L. Levico & L. Santo di Cembra & L. Serraia & L. Tovel \\
\hline elevation (m a.s.1.) & 449 & 1114 & 440 & 1194 & 974 & 1178 \\
\hline latitude $\mathrm{N}$ & $46^{\circ} 01^{\prime}$ & $45^{\circ} 56^{\prime}$ & $46^{\circ} 01^{\prime}$ & $46^{\circ} 11^{\prime}$ & $46^{\circ} 08^{\prime}$ & $46^{\circ} 15^{\prime}$ \\
\hline longitude E & $11^{\circ} 14^{\prime}$ & $11^{\circ} 15^{\prime}$ & $11^{\circ} 16^{\prime}$ & $11^{\circ} 12^{\prime}$ & $11^{\circ} 15^{\prime}$ & $10^{\circ} 57^{\prime}$ \\
\hline surface inflow & yes & no & yes & no & yes & no \\
\hline surface outflow & yes & no & yes & yes & yes & yes \\
\hline catchment area $\left(\mathrm{km}^{2}\right)$ & $49.3 *$ & 0.6 & 27 & n.a.** & 8.9 & 39.9 \\
\hline theoretical renewal time (y) & 3 & $<1$ & 1.1 & $<1$ & $<1$ & $<1$ \\
\hline area (ha) & 563 & 5 & 116 & 32 & 44 & 38 \\
\hline volume $\left(10^{3} \mathrm{~m}^{3}\right)$ & 149,000 & 381 & 12,942 & 192 & 3,140 & 7,367 \\
\hline max depth (m) & 47 & 17 & 38 & 15 & 18 & 39 \\
\hline epilimnion volume (\%) & 32 & 63 & 36 & 63 & 71 & 14 \\
\hline ice-covered in winter & no & yes & no/yes & yes & yes & yes \\
\hline predominant land-use & $\begin{array}{l}\text { agriculture, } \\
\text { urban, forest }\end{array}$ & $\begin{array}{l}\text { forest, } \\
\text { agriculture }\end{array}$ & $\begin{array}{l}\text { forest, } \\
\text { agriculture }\end{array}$ & forest & agriculture & forest \\
\hline trophic status & mesotrophic & mesotrophic & mesotrophic & mesotrophic & eutrophic & oligotrophic \\
\hline
\end{tabular}

cation (Gat 1995). In most studies regarding stable isotopes in lakes, attention is focused on water at isotopic equilibrium and lake stratification is considered a complicating factor (Benson 1994; Gat 1995; Nachiappan et al. 2002). This issue is simplified in lakes predominantly fed by deep groundwater having a constant isotope signal (Krabbenhoft et al. 1990; Blasch \& Bryson 2007) and in lakes with long water residence times, where the carry-over from year to year tends to dampen seasonal variations (Dincer 1968; LaBaugh et al. 1997; Gibson 2001). Instead, in lakes with short residence times, the isotope composition generally evolves ex novo every year since there is no carry over (Gibson et al. 2002; Gurrieri \& Furniss 2004).

In this study, we investigated multi-annual data of ${ }^{18} \mathrm{O} /{ }^{16} \mathrm{O}$ in lakes characterized by different hydrological regimes ( $>$ and $<1$ year renewal time) and size ( $>$ or $<50$ ha) to gain information about carry-over effects, water infiltration, extent of mixing, and stratification. We show that spatial and temporal variations in ${ }^{18} \mathrm{O} /{ }^{16} \mathrm{O}$ can indicate these hydrological characteristics which are not readily available by standard in-lake limnological analyses. Furthermore, we hypothesised that meteorologically particular years such as the year 2003 will leave a distinct fingerprint in isotope values.

\section{METHODS}

\subsection{Study Sites}

This work was part of different limnological studies on Trentino (Italy) lakes. Two large lowland lakes and four mid-altitude lakes were considered (Fig. 1). Table 1 gives some limnological characteristics, but detailed descriptions of the lakes can be found in Flaim et al. (2001b) for L. Caldonazzo, in Flaim et al. (2001a) for L. Serraia, in Borghi et al. (2006) for L. Tovel, in Corradini et al. (2007) for L. Lavarone, and in IASMA (1996-2000) for L. Levico and L. Santo. Some isotope 
data for L. Lavarone were taken from Corradini et al. (2007) and Filippi et al.(2007).

\subsection{Sampling}

Water samples were taken over the deepest part of each lake at various depths with a 2-L water sampler. Sampling frequency varied among lakes and was sporadic with ice-cover. L. Lavarone was sampled seasonally in 2003, 2004, and 2005. L. Santo was sampled seasonally in 2003 and monthly in 2004. L. Serraia was sampled monthly for a three year period (2002-2004). Isotope profiles for these lakes were taken at $0,2,5,10$, and $15 \mathrm{~m}$ depths. L. Tovel was sampled monthly from July 2001 to December 2003. Isotope profiles were taken at $0,1,2.5,5,10,15,20,25,30$, and $35 \mathrm{~m}$ depths. L. Caldonazzo was sampled bimonthly in 2003 and 2004 and isotope profiles were taken at $0,2.5,5,10,20$, 30,40 , and $47 \mathrm{~m}$ depths. L. Levico was sampled seasonally from May 2003 to November 2004 and isotope profiles were taken at $0,5,10,20,30$, and $37 \mathrm{~m}$ depths. Lake temperature profiles ( $1 \mathrm{~m}$ intervals) were taken for each lake at each sampling occasion with a multi-parametric probe (Hydrolab SD4a). Depth strata were attributed to the epilimnion or hypolimnion on the basis of the mean Relative Thermal Resistance (RTR) profiles (not shown) calculated on pluri-annual summer profiles (Wetzel 2001). Precipitation samples, collected monthly in polyethylene containers containing vaseline oil to prevent evaporation, were taken directly at the IASMA meteorological station at Lake Tovel. Mean 1983/2000 values for yearly precipitation and January and July temperatures were taken from the IASMA meteorological station at S. Michele a/A.

\subsection{Isotopic Analyses}

The ${ }^{18} \mathrm{O} /{ }^{16} \mathrm{O}$ of water was determined using an isotope ratio mass spectrometer (SIRA II, VG Isogas, Middlewich, UK) interfaced with an on-line automatic system that allows $\mathrm{CO}_{2} / \mathrm{H}_{2} \mathrm{O}$ equilibration (ISOPREP 18, VG Isotech, Middlewich, UK), according to the technique described by Epstein \& Mayeda (1953). The ${ }^{18} \mathrm{O} /{ }^{16} \mathrm{O}$ was expressed as delta per thousand $\left(\delta^{18} \mathrm{O} \%\right.$ ) as the deviation of the isotope ratio of the sample from the international reference standard V-SMOW (Vienna Standard Mean Ocean Water, IAEA-International Atomic Energy Agency, Vienna, Austria):

$$
\partial^{18} O=\frac{\left(\frac{{ }^{18} O}{{ }^{16} O}\right)_{\text {sample }}-\left(\frac{{ }^{18} O}{{ }^{16} O}\right)_{\text {standard }}}{\left(\frac{{ }^{18} O}{{ }^{16} O}\right)_{\text {standard }}} \times 1000
$$

Working in-house standards (tap water) calibrated against V-SMOW were periodically used to calibrate the measurements. Analytical uncertainty of $\delta^{18} \mathrm{O}$ measurement was $0.2 \%$.

\subsection{Statistical Analyses}

For each lake, samples for analysis of mixis and stratification were chosen on the basis of temperature profiles and of the lowest and highest coefficients of variation of the $\delta^{18} \mathrm{O}$ values along the water column, respectively. Differences in yearly spring values were tested by one-way ANOVA followed by post hoc multiple comparison (Tukey HSD). In case of heterogeneity of variances, non-parametric statistic (Kruskal-Wallis ANOVA by Ranks) was used. Differences in epilimnion and hypolimnion values during summer stratification for each lake were tested by Students' $t$-test. In case of heterogeneity of variances, non-parametric statistic (MannWhitney's $U$ - test) was used. To assess for meromixis, bottom $\delta^{18} \mathrm{O}$ values were compared to the rest of the water column (two-tailed Students' $t$-test). Epilimnetic enrichment, calculated as the difference between the mean spring overturn value for the entire water column and the mean summer epilimnion value, was related to altitude. The dependence of epilimnetic enrichment on altitude (continuous variable) and the year 2003/all other years (categorical variable) was investigated by ANCOVA. For this analysis, in addition to the six lakes considered, data from Lake Canzolino (540 m a.s.1.) for 1998 and Lake Lamar (714 m a.s.1.) for 2003 were also used. Limnological characteristics for these lakes can be found in IAMSA (1996-2000). All statistical analyses were done with the software Statistica 7.0.

\section{RESULTS}

\subsection{Isotope values of precipitation and local weather}

Mean monthly isotope values of precipitation at Tovel (i.e. rainfall or snow) (Fig. 2) generally showed a seasonal pattern with more depleted values in autumn/winter and more enriched values in summer (range $\sim 20 \%$ ). An exception was autumn 2002, with values similar to summer ones.

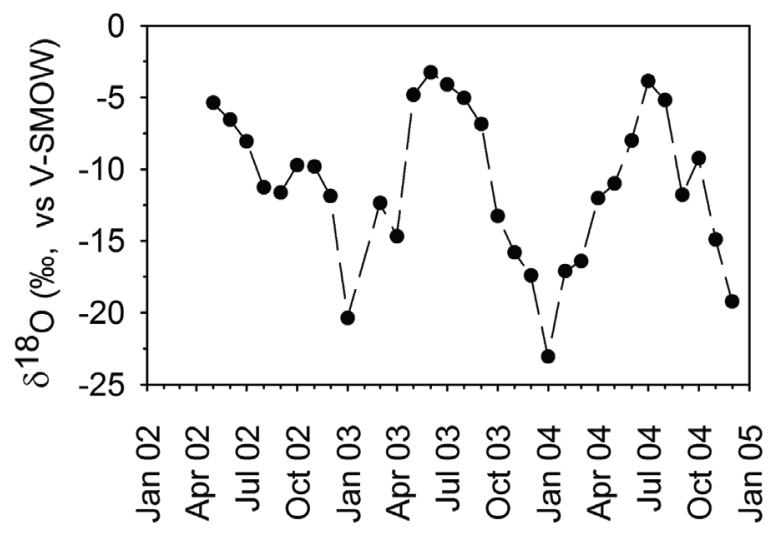

Fig. 2. $\delta^{18} \mathrm{O}$ pattern in precipitation for the period 2001-2004 taken from the Tovel meteorological station (1178 $\mathrm{m}$ a.s.1.). 

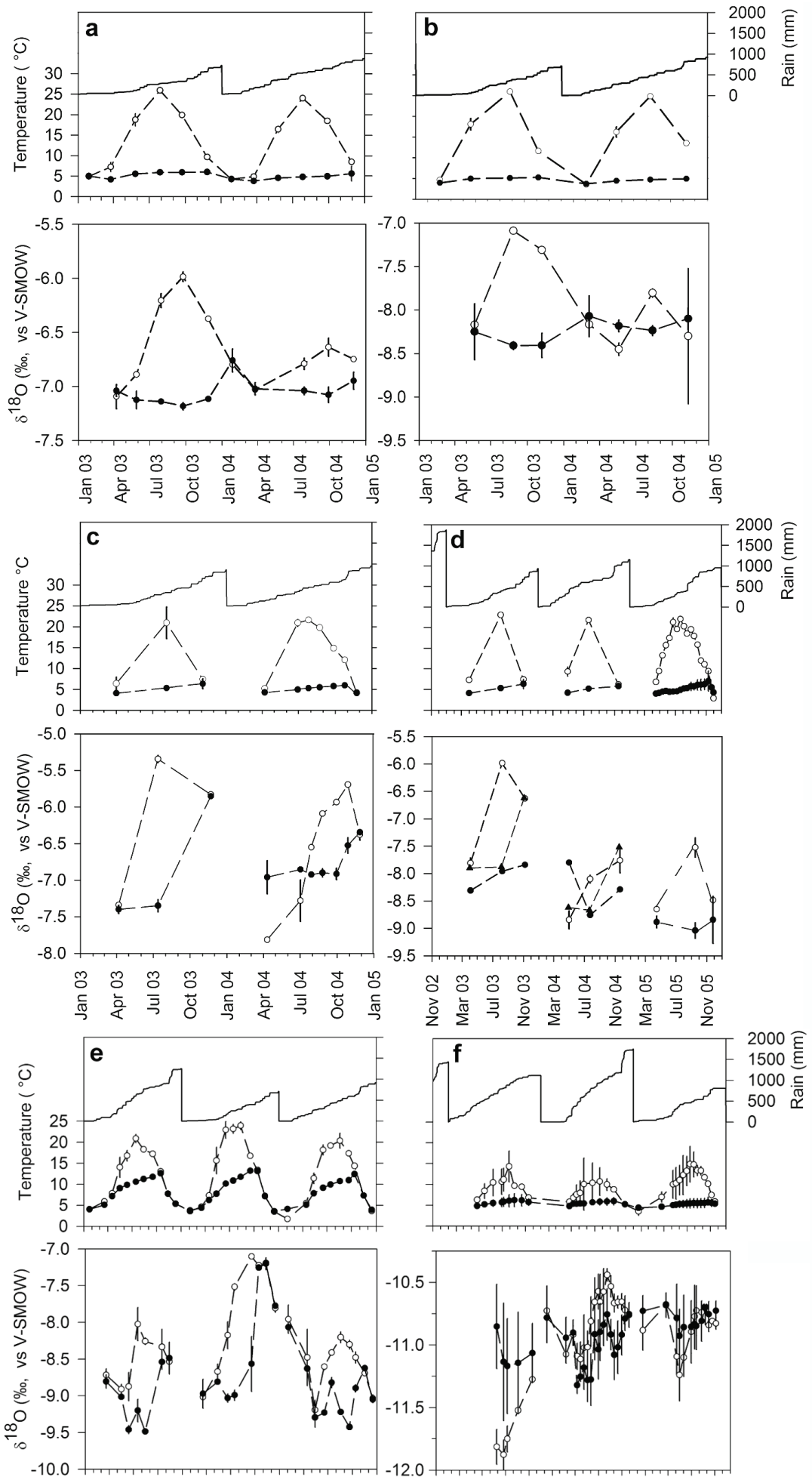

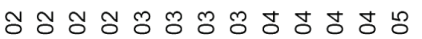

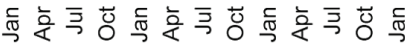

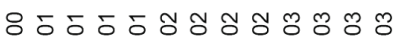

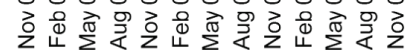

$--a-$ epilimnion $-\rightarrow-$ hypolimnion $\quad-\lrcorner-$ stratum of meromixis

Fig. 3. Precipitation (mm), and temperature $\left({ }^{\circ} \mathrm{C}\right)$ and lake $\delta^{18} \mathrm{O}$ values for L. Caldonazzo (a), L. Levico (b), L. Lavarone (c), L. Santo di Cembra (d), Serraia (e), and Tovel (f). Upper panel shows cumulative precipitation (continuous line) and temperature (white circles indicate epilimnion values, black circles indicate hypolimnion values). Lower panel shows mean $\delta^{18} \mathrm{O}$ values for epilimnion (white circles) and hypolimnion (black circles). Vertical bars indicate standard deviations. 
Tab. 2. Summary of statistical analysis of $\delta^{18} \mathrm{O}$ values for different limnological aspects in lakes studied. Significant results are in bold.

\begin{tabular}{|c|c|c|c|c|c|c|}
\hline$\delta^{18} \mathrm{O}$ values & L. Caldonazzo & L. Lavarone & L. Levico & L. Santo & L. Serraia & L. Tovel \\
\hline $\begin{array}{l}\text { probability of significant differences in spring } \\
\text { overturn values from year to year }\end{array}$ & 0.554 & 0.007 & 0.872 & - & 0.003 & 0.001 \\
\hline $\begin{array}{l}\text { number of times bottom values were different from } \\
\text { rest of water column at overturn (meromixis) for } \\
\text { years considered (n) }\end{array}$ & $\begin{array}{c}0 \\
(n=3)\end{array}$ & $\begin{array}{c}2 \\
(n=3)\end{array}$ & $\begin{array}{c}0 \\
(n=2)\end{array}$ & $\begin{array}{c}0 \\
(n=2)\end{array}$ & $\begin{array}{c}0 \\
(n=3)\end{array}$ & $\begin{array}{c}0 \\
(\mathrm{n}=3)\end{array}$ \\
\hline $\begin{array}{l}\text { probability of significant difference between } \\
\text { epilimnion and hypolimnion }\end{array}$ & 0.004 & 0.010 & 0.011 & 0.021 & 0.001 & 0.572 \\
\hline
\end{tabular}

The weather for the years 2001, 2004, 2005, and 2006 was similar to the $1983 / 2000$ mean for precipitation $(873 \mathrm{~mm})$ and for seasonal temperatures (January 0 ${ }^{\circ} \mathrm{C}$; July $22{ }^{\circ} \mathrm{C}$ ). The years 2000 and 2002 instead were exceptionally wet with intense autumn/winter precipitation (Fig. 3), and the year 2003 was dryer with high summer temperatures (July $25^{\circ} \mathrm{C}$ ). For Tovel, winter precipitation (21 December-20 March) was $267 \mathrm{~mm}$ in $2000-01,70 \mathrm{~mm}$ in $2002-03$, and only $1 \mathrm{~mm}$ in 2001-02 (Fig. 3).

\subsection{Mixing}

Year to year comparisons for homogeneous $\delta^{18} \mathrm{O}$ values at spring overturn (one-way ANOVA) showed significant differences among years for L. Lavarone, L. Serraia, and L. Tovel but not for L. Caldonazzo and L. Levico (Fig. 3; Tab. 2). Unfortunately, for L. Santo di Cembra the sampling date for spring 2004 was too early to completely reflect spring mixis.

$\delta^{18} \mathrm{O}$ values at autumn overturn tended to reflect the epilimnetic volume of the lake, with large lakes showing values closer to the hypolimnetic ones and small lakes showing values more similar to the epilimnetic ones.

\subsection{Meromixis}

Analysis of homogeneity between the $\delta^{18} \mathrm{O}$ values of the bottom layer and the rest of the water column at spring and autumn overturn ( $t$-test) did not show differences for L. Caldonazzo, L. Levico, L. Santo di Cembra, L. Serraia, and L. Tovel during the years studied (Tab. 2). For L. Lavarone instead (Fig. 3), the $\delta^{18} \mathrm{O}$ value of the $15 \mathrm{~m}$ bottom sample was significantly different from the mean value of the upper layers $(0,2.5,5$, and $10 \mathrm{~m}$ ) in spring and autumn 2003 and 2004, but not in 2005 (Fig. 3; Tab.2).

\subsection{Stratification}

Analysis of the difference between summer epilimnetic and hypolimnetic $\delta^{18} \mathrm{O}$ values for different years ( $t$-test) showed a statistically significant difference between the epilimnion and hypolimnion for each lake except L. Tovel (Tab. 2).

While in L. Tovel the epilimnetic $\delta^{18} \mathrm{O}$ values were not statistically different from the hypolimnetic ones, these values tended to show an unusual inverse pattern: the upper water layer had a lower $\delta^{18} \mathrm{O}$ value than the lower layer for all samples of 2001 and of 2003 at least until mid-July (Fig. 3). In 2002 instead, the lake tended to show the normal pattern of heavy isotope enrichment of surface waters.

Epilimnetic summer enrichment of ${ }^{18} \mathrm{O}$ with respect to spring values was directly related to altitude (Fig. 4). L. Tovel was excluded from this analysis because of isotope homogeneity along the water column. ANCOVA analysis showed that the slopes of the hot year '2003' and 'all other years' regressions were not significantly different $(P=0.8)$, while the intercepts were significantly different $(P<0.0001)$.

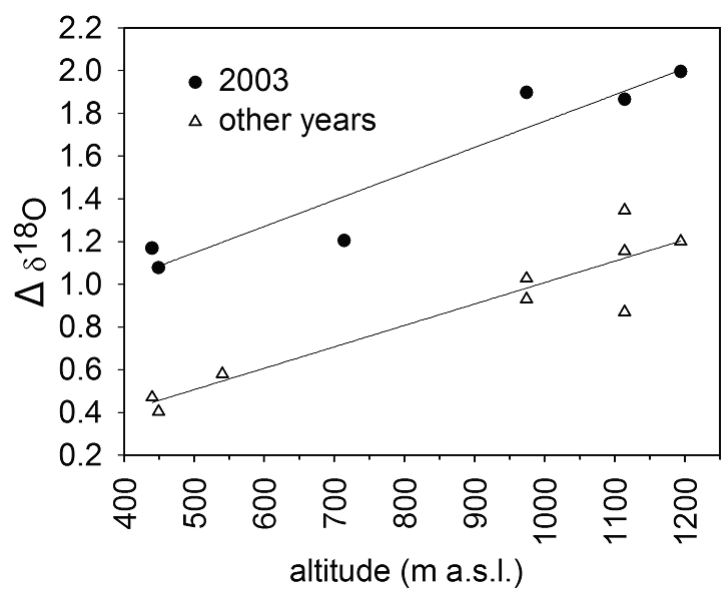

Fig. 4. Linear regression of epilimnetic enrichment dependent on altitude for the year 2003 and for all other years considered, respectively.

\subsection{Variations in summer hypolimnetic values}

For L. Caldonazzo, L.Levico, and L. Santo di Cembra, the $\delta^{18} \mathrm{O}$ values of the hypolimnion did not vary in the dry 2003 and wet 2004 summers. For L. Lavarone, a strong increase in the hypolimnetic $\delta^{18} \mathrm{O}$ value (September 2005) coincided with a strong storm event $(125 \mathrm{~mm})$ before the sampling date. For L. Serraia, the summer hypolimnetic $\delta^{18} \mathrm{O}$ values generally did not vary, but after a major storm $(128 \mathrm{~mm})$ prior to the July 2004 samplings, $\delta^{18} \mathrm{O}$ values increased substantially in the hypolimnion while stratification was not effected as shown by stable temperature profiles (Fig. 3). 


\section{DISCUSSION}

In hydrological applications of isotopes, lack of homogeneity along the water column is considered a complicating factor for water mass balance studies (Gat 1995; Nachiappan et al. 2002). Our work instead, emphasised the information that could be gained from variations of $\delta^{18} \mathrm{O}$ values in lakes during overturn and stratification without having access to hydrological data from the catchment, necessary to carry out water mass balance calculations.

\subsection{Precipitation}

Despite their importance for hydrological studies (Longinelli \& Selmo 2003), multi-annual regional data of stable isotope values in precipitation are rare. Our data represent a contribution to the understanding of isotope patterns in precipitation at mid-altitude locations. Generally, values were in line with the seasonal pattern seen in Longinelli \& Selmo (2003) with summer values richer in heavy isotopes and winter values lighter. However, seasonal difference in $\delta^{18} \mathrm{O}$ values were higher than those observed by Longinelli \& Selmo (2003) at lower elevations (20 and $400 \mathrm{~m}$ a.s.l., respectively) and in areas closer to the coast.

\subsection{Mixing}

Along with isothermal conditions, periods of water mixing at spring overturn were generally characterised by homogeneous isotope values along the water column. There were however, significantly different year to year variations in L. Lavarone, L. Serraia, and L. Tovel. Other authors (Gibson et al. 2002; Gurrieri \& Furniss 2004) have already noted that in lakes with short residence times, the isotope composition can evolve with no carry over from year to year. These yearly differences in spring isotope values suggest that L. Lavarone, L. Serraia, and L. Tovel were substantially flushed in order to show different $\delta^{18} \mathrm{O}$ values. This hypothesis was supported by the occurrence of an unusually enriched isotope value in autumn rainfall which left a unique fingerprint on lake isotope values in L. Lavarone. We suggest that these heavy rains $(455 \mathrm{~mm}$ in November 2002- data not shown) with a high $\delta^{18} \mathrm{O}$ value (-7.6\% - unpublished data, ACQUAPAST), flushed the lake as shown by a spring value of $-7.8 \% \delta^{18} \mathrm{O}$ in the $0-10 \mathrm{~m}$ layer $(>90 \%$ of the lake volume) (Fig. 3).

Mean spring values for L. Caldonazzo and L. Levico instead, were essentially the same in the two consecutive years that were studied. Lakes with long renewal times showed a carry over effect, and temporal stability of $\delta^{18} \mathrm{O}$ values could be an indirect evidence of their longer renewal times ( $>1$ year).

Autumn mixis produced a different isotope pattern in large and small lakes with $\delta^{18} \mathrm{O}$ values in large lakes reflecting summer hypolimnetic values and in small lakes reflecting epilimnetic values. We suggest that this reflects the ratio of epilimnetic to hypolimnetic water volume. In fact, George \& Hurley (2003) also underline the importance of this parameter for lakes.

\subsection{Meromixis}

For many reasons, such as lake position, timing of ice-out, and salinity gradients, lakes often do not undergo complete spring mixing (Wetzel 2001) with repercussions on anoxia (Nürnberg 1995) and phosphorus release (Christophoridis \& Fytianos 2006). For L. Lavarone and $\mathrm{L}$. Tovel the issue of meromixis could be clarified in our study. Complete spring overturn at L. Lavarone occurred only in two of the three years studied. Mixing was probably hindered by the lake's sheltered position and late ice-out, followed by a quick warming of the water mass. In our study, with only a small number of samples available, temperature and oxygen could not fully detect degree and extent of mixing, while $\delta^{18} \mathrm{O}$ analysis proved to be a more sensitive measure of hypolimnion homogeneity. L. Tovel was long considered a meromictic lake (Paganelli 1992) notwithstanding its short renewal time. $\delta^{18} \mathrm{O}$ depth profiles of this study showed that the bottom layers of this lake are mixed, indicating that it can no longer be considered meromictic.

\subsection{Stratification}

Seasonal and depth changes in isotope ratios along the water column provided a novel perspective of stratification intensity in lakes. The strong difference between epilimnion and hypolimnion isotope values indicated marked stratification for all lakes studied except L. Tovel.

In L. Serraia, metalimnetic removal of water for hydro-electric purposes was hypothesised as a possible cause of interference with summer stratification (Volpi 2002). Such entrainment events can result in phosphorus release to the epilimnion and thereby contribute to algal blooms (Soranno et al. 1997). Our $\delta^{18} \mathrm{O}$ study indicated that de-stratification did not occur in Serraia at least in the three summers studied.

Lake Tovel was an exception to the usual summer isotope pattern, even if the lake was located at similar elevations as L. Serraia, L. Lavarone, and L. Santo di Cembra. It was the only lake where the isotope pattern did not follow thermal stratification; instead the upper layer tended to be more isotopically depleted than the lower layer, even if the difference was not statistically significant. Over $80 \%$ of water inflow to the lake originates through shallow peri-lacustrine springs fed by a large underground aquifer (Borsato \& Ferretti 2006). Furthermore, underground water is isotopically conservative in nature (Krabbenhoft et al. 1990; Blasch \& Bryson 2007). Therefore, we suggest that in L. Tovel the isotope values of the inflow and ultimately of the lake, essentially reflected the timing of aquifer recharge: depleted values with winter snow and enriched values 
with spring rains. In fact, in wet winters $(2000 / 1$ and 2002/3) ${ }^{18} \mathrm{O}$ depleted water was introduced to the epilimnion while in dry winters (2001/2) snowmelt was reduced and inflow originated from more isotopically enriched spring rain. A partial exception to this inverse pattern of isotope depletion of the upper layer was during the second half of the hot 2003 summer when there was no underground water input to the lake as seen from a decrease in lake level (Borsato \& Ferretti 2006). Even in the exceptionally hot 2003 summer, however, this enrichment was not enough to establish a statistically significant separation between the heavy isotope content of the upper and lower layer. Gurrieri \& Furniss (2004) also noted that lakes occupying deep north-facing cirques show reduced evaporation because of lower solar radiation.

In their recent model, Gibson and colleagues (2008) show that seasonality has an influence on evaporation along a latitude gradient. We found a strong direct relation between intensity of summer ${ }^{18} \mathrm{O}$ isotope enrichment of the epilimnion and lake elevation for all lakes considered, except L. Tovel. This relationship was attributed to the effect of lake evaporation. In fact, with increasing altitude, atmospheric pressure decreases and evaporation increases (Rozanski et al. 2000). Obviously temperature also affects evaporation and particularly hot years such as 2003 can leave a distinct isotope fingerprint. The year 2003 was one of the hottest on record and determined important changes in temperature and oxygen for large European lakes (Jankowski et al. 2006).

\subsection{Variations in summer hypolimnetic values}

We used variations in summer hypolimnetic $\delta^{18} \mathrm{O}$ values to assess deep water inflow to lakes during summer stratification. In L. Caldonazzo, L. Levico, and L. Santo di Cembra, the hypolimnion always showed a stable isotope signal, even with different precipitation values for the years considered (Fig. 3). For L. Santo di Cembra, a hydrological poorly known lake, the stability of the $\delta^{18} \mathrm{O}$ values suggested that there was little or not underground water inflow into the hypolimnion. For L. Lavarone and L. Serraia instead, alterations in hypolimnetic isotope equilibrium were found to occur only after storm events (Fig. 3), suggesting infiltration of groundwater or subsurface water into the hypolimnion. Our results further indicated that for L. Lavarone, inflow was by underground seepage at a depth that involved predominantly the $10 \mathrm{~m}$ depth isopleths but less so the deeper portion of the lake. For L. Serraia, changes in hypolimnetic equilibrium also occurred after strong precipitation events, but the isotope ratio was stable when a storm was preceded by a dry period (August 2005, a period preceded by $\mathrm{ca} 50$ days without rainfall). This suggests that after a long dry period, rain was absorbed by the under-saturated soil, and therefore had no influence on the lake.

\subsection{Proposed general scheme}

Without further studies on small water bodies we can only speculate on the limnological characteristics of the majority of lakes (Hanson et al. 2007). Based on our results, we propose a scheme which summarises the different patterns of $\delta^{18} \mathrm{O}$ values in the epilimnion and hypolimnion for small and large lakes, usually characterised by a short and a long water residence time, and different epilimnetic to hypolimnetic ratios in relation to depth, respectively (Fig. 5; Tab. 1).

For lakes with short residence time, the $\delta^{18} \mathrm{O}$ values at spring overturn can change depending on the water source (i.e. rain or snow; surface or underground water) and the intensity of winter precipitation. With stratification, epilimnetic and hypolimnetic $\delta^{18} \mathrm{O}$ values will separate. In detail, the enrichment in epilimnetic $\delta^{18} \mathrm{O}$ values will depend on air temperatures and lake elevation. Hypolimnetic values will be stable if there are no groundwater or subsurface seepage into this layer, otherwise, $\delta^{18} \mathrm{O}$ values can show marked fluctuations. With autumn overturn, the water column mixes once again and the difference in the $\delta^{18} \mathrm{O}$ value with respect to the spring value will mainly depend on the volume of the epilimnion. In autumn and winter, the usually isotopically depleted precipitation will lower the $\delta^{18} \mathrm{O}$ value of the lake. Furthermore, in temperate climates, late year precipitation is a considerable part of the yearly rainfall (Eccel \& Saibanti 2007) and can flush the whole lake leading to a complete reset of the system.

For lakes with longer residence times, the pattern is similar, but spring values tend to be stable since there is a carry over effect from one year to the next. In addition, the epilimnetic volume in deep lakes is usually smaller than the hypolimnetic volume leading to $\delta^{18} \mathrm{O}$ values at autumn mixis that are more similar to summer hypolimnetic values.

\section{CONCLUSIONS}

Our multi-year study of $\delta^{18} \mathrm{O}$ values along a temporal and vertical gradient in six lakes with contrasting hydrological characteristics provided a deeper understanding of hydrological processes. In fact, one of the most important questions facing lake restoration and management initiatives is "where is the origin of lake water?". For most large lakes this question has already been sufficiently evaluated, but for many small lakes hydrological information is not readily available. Apart from Lake Tovel, which proved an interesting exception, the other lakes considered showed the general pattern described in figure 5. In particular, our approach of studying the evolution of epilimnetic and hypolimnetic $\delta^{18} \mathrm{O}$ values, proved to be useful in discerning water movements in small lakes, and provided insights into the extend of lake renewal, mixis, stratification, and groundwater infiltration. The use of stable isotopes can be used as a fingerprinting tool to indicate the extent and influence of extraordinary events on lakes. 


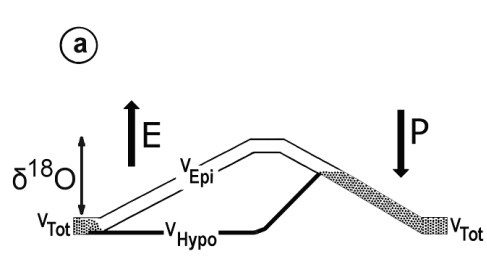

M A M J J A S O N D J F M small lakes

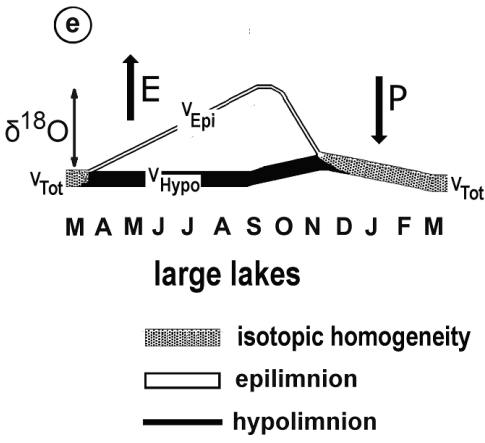

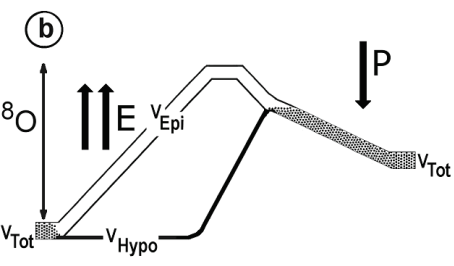

MA M J J A S O N D F M

(C)

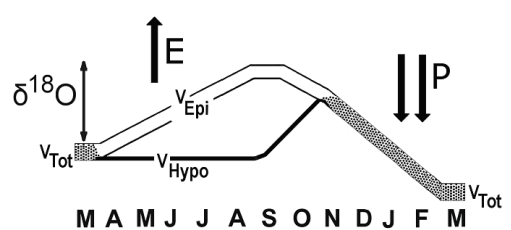

(d)

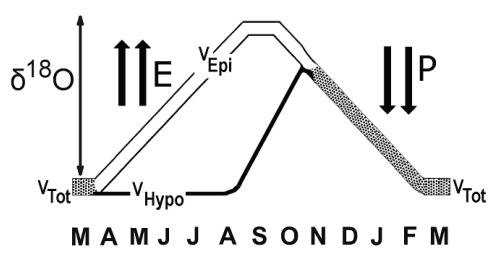

Fig. 5. Schematic diagram of the seasonal evolution in stable isotope ratios in small (a-d) and in large lakes (e). The start of the limnological year, corresponding to spring overturn, shows isotopic homogeneity for the entire water mass $\left(\mathrm{V}_{\text {Tot }}\right)$. The degree of evaporation (E) producing epilimnetic enrichment, depends prevalently on summer temperatures (average summer $\uparrow$; hot summer $\uparrow \uparrow$ ), while the degree of winter isotope depletion depends prevalently on precipitation (P) (average winter $\downarrow$; wet winter $\downarrow \downarrow$ ). In small lakes various patterns are seen: : a - 'average' year; b - hot summer; $\mathbf{c}$ - wet winter; $\mathbf{d}$ - hot summer and wet winter, which affect the following year's isotope value. In large lakes (e) with smaller epilimnetic volume one pattern is dominant. Please note that in cases (a), (d), and (e) isotope values are similar in consecutive springs while in cases (b) and (c) they are different. Note also the different thickness of epilimnetic $\left(\mathrm{V}_{\mathrm{Epi}}\right)$ and hypolimnetic $\left(\mathrm{V}_{\mathrm{Hypo}}\right)$ volume in large/deep and small/shallow lakes (see text for explanation).

\section{ACKNOWLEDGEMENTS}

This work was carried out within the research activity funded by IASMA and partly funded by the SALTO, OLOAMBIENT and CERCA Research Grants (Province of Trento, Italy). The authors thank A. Borsato for useful comments on an earlier draft and P. Ferretti for use of some isotope data from Tovel. The authors also thank V. Pinamonti and G. Leonardi for sampling and A. Tonon for technical support.

\section{REFERENCES}

Ambrosetti, W., L. Barbanti \& N. Sala. 2002. Residence time and physical processes in lakes. J. Limnol., 62(Suppl. 1): $1-15$.

Benson, L.V. 1994. Stable isotopes of oxygen and hydrogen in the Truckee River-Pyramid Lake surface-water system. 1. Data analysis and extraction of paleoclimatic information. Limnol. Oceanogr., 39: 344-355.

Blasch, K.L. \& J.R. Bryson. 2007. Distinguishing sources of ground water recharge by using $\delta 2 \mathrm{H}-\delta 18 \mathrm{O}$. Ground Water 45(3):294-308.

Borghi, B., A. Borsato, M. Cantonati, F. Corradini, \& G. Flaim. 2006. Studio sul mancato arrossamento del Lago di Tovel. Studi Trent. Sci. Nat., Acta Biol., 81: 1-476.
Borsato, A. \& P. Ferretti. 2006. Hydrological monitoring of Lake Tovel and its catchment. Studi Trent. Sci. Nat., Acta Biol., 81: 205-223.

Christophoridis, C. \& K. Fytianos. 2006. Conditions affecting the release of phosphorus from surface lake sediments. $J$. Environ. Qual., 35: 1181-1192.

Corradini, F., M. Tolotti, D. Calliari, \& F. Fiamingo. 2004. Influence of environmental factors on diatoms and dinoflagellates in Lake Tovel (Trentino, Italy). Verh. int. Ver. Limnol., 29: 469-472.

Corradini, F., S. Boscaini, G. Flaim, M.L. Filippi, A. Borsato \& M. Zandonati. 2007. Physics, hydrochemistry and hydrology of Lavarone Lake (Trentino Italy). Studi Trent. Sci. Nat., Acta Geol., 82: 175-187.

Dincer, T. 1968. The use of oxygen 18 and deuterium concentrations in the water balances of lakes. Wat. Res., 4: 12891306.

Eccel, E. \& S. Saibanti. 2007. Climatic setting of the Lavarone-Vezzena Plateau in the general context of Trentino. Studi Trent. Sci. Nat., Acta Geol., 82: 111-121.

Epstein, S. \& T. Mayeda. 1953. Variation of ${ }^{18} \mathrm{O}$ content of water from natural sources. Geochim. Cosmochim. Acta., 4: 213-224.

Flaim, G., F. Corradini \& N. Buesing. 2001a. Anthropogenically induced phytoplankton blooms in Lake Serraia, N. Italy. Verh. int. Ver. Limnol., 27: 3370-3373.

Flaim, G., Corradini, F. \& V. Pinamonti. 2001b. Lake Caldonazzo: 25 years of trophic evolution and restoration operations. Atti Associazione Italiana Oceanogr. e Limnol., 14(1): 239-248. 
Filippi, M. L., C. Spötl, F. Corradini, M. Mandelli \& M. Tardio. 2007. Sedimentation in lacustrine environments: study by means of sediment traps at Lago di Lavarone (NE Italy). Studi Trent. Sci. Nat., Acta Geol., 82: 189-202.

Gat, J.R. 1995. Stable isotopes of fresh and saline lakes. In: A. Lerman, D. Imboden \& J. Gat (Eds), Physics and Chemistry of Lakes. Springer, Berlin: 139-165.

George, D. G. \& M. A. Hurley. 2002. Using a continuous function for residence time to quantify the impact of climate change on the dynamics of thermally stratified lakes. J. Limnol., 62(Suppl. 1): 21-26.

Gibson, J.J. 2001. Forest-tundra water balance signals traced by isotopic enrichment in lakes. J. Hydrol., 251: 1-13.

Gibson, J.J., E.E. Prepas \& P. McEachern. 2002. Quantitative comparison of lake throughflow, residency, and catchment runoff using stable isotopes: modelling and results from a regional survey of Boreal lakes. J. Hydrol., 262: 128-144.

Gibson, J.J., S. J. Birks \& T. W. D. Edwards. 2008. Global prediction of $\delta_{\mathrm{A}}$ and $\delta^{2} \mathrm{H}-\delta^{18} \mathrm{O}$ evaporation slopes for lakes and soil water accounting for seasonality. Global Biogeochem. Cycles, 22, GB2031, doi:10.1029/2007GB002997

Grey, J., A. Kelly, S. Ward, N. Sommerwerk \& R.I. Jones. 2004. Seasonal variation in carbon and nitrogen stable isotope ratios of chironomid larvae from four eutrophic lakes. Freshwat. Biol., 49: 681-689.

Guerrieri, J.T. \& G. Furniss. 2004. Estimation of groundwater exchange in alpine lakes using non-steady mass-balance methods. J. Hydrol., 297: 187-208.

Hanson, P, C., S. R. Carpenter, J.A. Cardille, M.T. Coe \& L.A. Windslow. 2007. Small lakes dominate a random sample of regional lake characteristics. Freshwat. Biol., 52: 814-822.

IASMA. 1996-2000. Annual Reports on the Limnological Characteristics of Trentino lakes. Istituto Agrario di San Michele all'Adige, Trento. (in Italian).

Jankowski, T., D.M. Livingstone, H. Bührer, R. Forster \& P. Niederhauser. 2006. Consequences of the 2003 European heat wave for lake temperature profiles, thermal stability, and hypolimnetic oxygen depletion: Implications for a warmer world. Limnol. Oceanogr., 51: 815-819.

Krabbenhoft, D. P., C.J. Bowser, M.P. Anderson, \& J.W. Valley. 1990. Estimating groundwater exchange with lakes 1 . The stable isotope mass balance method. Wat. Resour. Res., 26: 2445-2453

LaBaugh, J.W., T.C. Winter, D.O. Rosenberry, P.F. Schuster, M.M. Reddy \& G.R. Aiken. 1997. Hydrological and chemical estimates of the water balance of a closed basin lake in north central Minnesota. Water Res. Research, 33: 2799-2812.

Lehner, B. \& P. Döll. 2004. Development and validation of a global database of lakes, reservoirs and wetlands. $J$. Hydrol., 296: 1-22.

Longinelli, A. \& E. Selmo. 2003. Isotopic composition of precipitation in Italy: a first overall map. J. Hydrol., 270: 75-88.

McEachern, P., E.E. Prepas \& D.S. Chanasyk. 2006. Landscape control of water chemistry in northern boreal streams of Alberta. J. Hydrol., 323: 303-324.

Nachiappan, Rm. P., B. Kumar \& Rm. Manickavasagam. 2002. Estimation of subsurface components in the water balance of Lake Nainital (Kumaun Himalaya, India) using environmental isotopes. Hydrol. Sci. 47(S): S41-S54.

Nürnberg, G.K. 1995. Quantifying anoxia in lakes. Limnol. Oceanogr., 40: 1100-1111.

Obertegger, U., G. Flaim, M.G. Braioni, R. Sommaruga, F. Corradini \& A. Borsato. 2007. Water residence time as a driving force of zooplankton structure and succession. Aquat. Sci., 69: 575-583.

Paganelli, A. 1992. Lake Tovel (Trentino): limnological and hydrobiological aspects. Mem. Ist. ital. Idrobiol., 50:225-257.

Rozanski, K., K. Fröhlich, W.G. Mook \& W. Stichler. 2000. Volume III Surface Water. In: W.G. Mook (Ed.), Environmental Isotopes in the Hydrological Cycle: Principles and Applications. IAEA, Vienna: 59-92.

Soranno, P.A., S.R. Carpenter \& R.C. Lathrop. 1997. Internal phosphorus loading in Lake Mendota: response to external loads and weather. Can. J. Fish. aquat. Sci., 54: 1883-1893.

Volpi, E. 2002. Il lago eutrofizzato. In G. Andreotti, G. Cainelli \& C. Maschio (Eds). Lake Serraia, the ways towards restoration. Rotary Incontri International - District 2060 Trento Italy: 125 pp. (in Italian).

Wetzel, R. G. 2001. Limnology - Lake and River Ecosystems. Academic Press, New York: 1006 pp.

Williams, P., M. Whitfield, J. Biggs, B. Bray, G. Fox, P. Nicolet \& D. Sear. 2003. Comparative biodiversity of rivers, streams, ditches and ponds in an agricultural landscape in southern England. Biol. Conserv., 115: 329-341.

Winter, T.C. 1995 . Recent advances in understanding the interaction of groundwater and surface water. Review of Geophysics, Suppl.: 985-994. 